\title{
PENGARUH CAMPURAN KONSENTRAT PROTEIN JAGUNG DAN TEPUNG TEMPE TERHADAP ANGKA LEMPENG TOTAL MI TAPIOKA
}

\author{
Nanda Triandita \\ Program Studi Ilmu dan Teknologi Pangan Fakultas Pertanian, Universitas \\ Garut \\ E-mail : nandatriandita2@gmail.com
}

\begin{abstract}
ABSTRAK
Belum diketahui, apakah tepung tapioka yang ditambahkan campuran konsentrat protein jagung (KPJ) dan tepung tempe kedelai (TTK), dapat menghasilkan mi yang menyerupai dari terigu. Penelitian menggunakan Rancangan Acak Lengkap (RAL) dengan 5 perlakuan dan 3 ulangan. Perlakuan penelitian adalah perbandingan KPJ : TTK A (5 : 25); B(10:20); C(15:15); D(20:10); E(25: 5) terhadap $70 \%$ tepung tapioka. Data dianalisis dengan uji F dan Duncan's New Multiple Range Test (DNMRT) pada taraf 5\%. Hasil penelitian menunjukkan bahwa mi tapioka dengan penambahan KPJ dan TTK berpengaruh myata terhadap karakteristik mutu mi. Mi tapioka yang dihasilkan dari campuran KPJ dan TTK (10:20) adalah yang terbaik.
\end{abstract}

\section{PENDAHULUAN}

Ubi kayu (Manihot esculenta Crantz) merupakan salah satu umbi-umbian yang banyak ditemukan di Indonesia. Ubi kayu biasa dikonsumsi dalam bentuk singkong rebus, singkong goreng, keripik, tape, dan lain-lain. Pada skala industri ubi kayu diolah menjadi gaplek, tepung gaplek, dan tepung tapioka. Salah satu produk yang dapat dibuat dari tapioka adalah mi kering. Menurut SNI 01-29741992, mi kering adalah produk makanan kering yang dibuat dari tepung terigu, dengan atau tanpa penambahan bahan makanan lain dan bahan makanan yang diizinkan, berbentuk khas mi. Syarat mutu mi kering harus mengandung protein minimal $8 \% \mathrm{~b} / \mathrm{b}$.

Pembuatan mi tapioka masih terdapat kekurangan zat gizi protein yang penting bagi tubuh. Kekurangan protein dapat memanfaatkan produk serealia yaitu jagung, dimana akan memanfaatkan protein dari jagung dengan membuatnya sebagai konsentrat protein jagung dan produk kacang-kacangan tempe dijadikan sebagai tepung tempe. 
Menurut Azima (1993), konsentrat protein jagung mengandung protein berkisar antara 26-34 \%, sedangkan kadar protein pada bahan baku jagung berkisar antara 8-12,27 \%. Asam amino pembatas pada jagung yaitu lisin, dan harus dikomplementasi dengan bahan pangan lain agar asam amino lisin meningkat.

Tempe merupakan makanan yang mengalami proses fermentasi dari bahan baku kedelai kelompok kacang-kacangan yang kaya akan asam amino lisin, tetapi terbatas asam amino metionin. Pada tempe terkandung protein sebanyak 20,8 gr/100 gr bahan (TKPI, 2009), dimana pada tempe kualitas protein lebih baik dari kedelai utuh, karena adanya proses fermentasi dapat menurunkan senyawa antigizi pada kedelai. Tepung tempe merupakan tepung yang diperoleh dari proses pengeringan tempe. Menurut Azima (1994), tepung tempe mengandung protein sebesar $34,36 \%$.

\section{METODE PENELITIAN}

Penelitian dilakukan di Laboratoriun Teknologi Hasil Pertanian, Fakultas Teknologi Pertanian, Universitas Andalas. Bahan yang digunakan dalam penelitian ini adalah tapioka, jagung, tempe, dan air. Tapioka cap Tani dan tempe yang diperoleh di Pasar Raya Padang. Jagung varietas pioneer 2 diperoleh dari Pasaman, Sumatera Barat. Bahan yang digunakan untuk analisis aquades, $\mathrm{H}_{2} \mathrm{SO}_{4}$ pekat, tablet kjedal, $\mathrm{NaOH}, \mathrm{K}_{2} \mathrm{SO}_{4} 10 \%$, Alkohol 95\%, Hexan, $\mathrm{NaOH} 1 \mathrm{~N}$, $\mathrm{HCl} 1 \mathrm{~N}$. Alat yang digunakan untuk analisis adalah pemanas kjedahl, labu kjedahl, alat destilasi, erlenmeyer, penangas air, alat ekstraksi soxhlet, labu lemak, kertas saring, tabung sentrifus, pipet, gelas piala, water bath, hot plate, magnetic stirrer, cawan porselen, cawan aluminium, neraca analitik, oven, desikator, tanur, sentrifus, Colori meter ColorFlex EZ.

Penelitian menggunakan Rancangan Acak Lengkap (RAL) dengan 5 perlakuan dan 3 kali ulangan. Data yang diperoleh dianalisis secara statistik dengan uji F, kemudian dilanjutkan dengan uji Duncan's New Multiple Range Test (DNMRT) pada taraf 5\%. Adapun rancangan penelitian adalah A $(70 \%$ Tapioka : 5\% Konsentrat Protein Jagung : 25\% Tepung Tempe), B (70\% Tapioka : 10\% Konsnetrat Protein Jagung : 20\% Tepung Tempe), C (70\% Tapioka : 15\% Konsentrat Protein Jagung : 15\% Tepung Tempe), D (70\% Tapioka : $20 \%$ Konsentrat Protein Jagung : 10\% Tepung Tempe), dan E (70\% Tapioka : 25\% Konsentrat Protein Jagung : 5\% Tepung Tempe).

Tahapan penelitian yang dilakukan adalah pembuatan kosentrat protein jagug (kjp), pembuatan tepung tempe (tt) dan aplikasi konsentrat protein jagung serta tepung tempe pada mi tapioka. Analisis dilakukan terhadap bahan baku meliputi proksimat (AOAC,1995) dan analisis produk mi tapioka meliputi proksimat dan fisik. 


\section{Pembuatan Konsentrat Protein Jagung (Azima, 1993)}

Jagung dibersihkan dan dipisahkan dari bonggolnya, dilakukan pengecilan ukuran, pisahkan lembaga dengan perendaman dalam air. Setelah pemisahan lembaga, dilakukan perendaman dalam larutan natrium metabisulfit $0,3 \%$ selama 30-36 jam untuk memisahkan matriks protein dan pati. Dilakukan pengecilan ukuran sampai halus. Selanjutnya dilakukan sentrifugasi dengan kecepatan 6000 rpm selama 30 menit, kumpulkan gluten basah yang diperoleh. Gluten basah yang diperoleh dilakukan pemisahan lemak dengan pelarut lemak selama 5 jam dan dilakukan pemisahan dengan sentrifugasi dengan kecepatan 6000 rpm selama 15 menit. Lalu dilakukan pencucian dengan air panas suhu $70^{\circ} \mathrm{C}$ selama 1 jam, dan dilakukan sentrifugasi kembali dengan kecepatan 6000rpm selama 30 menit. Endapan yang diperoleh dilakukan pengeringan pada oven hingga kadar air 10$14 \%$. Endapan kering yang diperoleh dilakukan pengecilan ukuran hinggan lolos 100 mesh.

\section{Pembuatan Tepung Tempe}

Tempe yang diperoleh dibersihkan dari bungkusnya, dilakukan pengirisan untuk memudahkan pengeringan dan dilakukan pengeringan hingga kadar air 1014\%. Setelah itu dilakukan penepungan dengan cara penghancuran dengan blender. Lalu dilakukan pengayakan lolos ukuran 100 mesh.

\section{Pembuatan Mi Kering Tapioka (Triandita, 2017)}

Timbang bahan sesuai perlakuan. 70 gram tapioka digunakan sebagai binder, dan dipanaskan dengan $140 \mathrm{~mL}$ air, setelah membentuk gel dicampurkan sisa tapioka dan campuran konsentrat protein jagung dan tepung tempe menjadi adonan hingga kalis, dilanjutkan dengan penggilingan menjadi lembaran sebanyak dua kali dan dilanjutkan dengan pencetakan menjadi mi. untuk menjadikan menjadi mi tapioka kering dilanjutkan dengan pengukusan, dan pengeringan pada oven pada suhu $100^{\circ} \mathrm{C}$ selam 1 jam.

\section{Lempeng Total (Fardiaz, 1993)}

Penentuan jumlah total mikroba pada lempeng total menggunakan media PCA 22,5 gram dan 1L aquades dengan metode tuang dan total koloni dihitung dengan SPC (Standart Plate Count). Sterilisasi media dan bahan lain pada suhu $121^{\circ} \mathrm{C}$ selama 15 menit menggunakan autoclave. Lakukan pengenceran sampai pengenceran $10^{-4}$. Pipet sebanyak $1 \mathrm{ml}$ sampel yang telah diencerkan kedalam cawan petri steril, kemudian tambahkan 15-20 ml media PCA cair steril. Inkubasi pada suhu $37^{\circ} \mathrm{C}$ selama 48 Jam. Perhitungan mikroba yang tumbuh dengan Coloni Counter. 


\section{HASIL DAN PEMBAHASAN}

\section{Angka Lempenng Total}

Hasil sidik ragam angka lempeng total pada mi kering tapioka bahwa penambahan konsentrat protein jagung dan tepung tempe berpengaruh sangat nyata $(\mathrm{P}<0,01)$ terhadap angka lempeng total mi kering tapioka Hal ini terlihat pada signifikan $0,00(\mathrm{P}<0,01)$.

Tabel 1. Rataan Angka Lempeng Total Mi Kering Tapioka Dengan Penambahan Campuran Konsentrat Protein Jagung Dan Tepung Tempe

\begin{tabular}{|c|c|c|c|}
\hline Perlakuan & \multicolumn{3}{|c|}{ Angka lempeng total (koloni/gram) } \\
\hline B (70\% Tapioka : $10 \%$ & & $6,0 \times 10^{4}$ & $\mathrm{a}$ \\
\hline KPJ:20\%T.Tempe) & & $2,6 \times 10^{5}$ & \\
\hline A (70\% Tapioka : $5 \%$ KPJ : $25 \%$ & $\mathrm{~b}$ & & \\
\hline T.Tempe) & & $2,7 \times 10^{5}$ & \\
\hline D (70\% Tapioka : 20\% KPJ:10\% & $\mathrm{b}$ & & \\
\hline T.Tempe) & & $2,7 \times 10^{5}$ & \\
\hline E (70\% Tapioka : $25 \%$ KPJ : $5 \%$ & $\mathrm{~b}$ & & \\
\hline T.Tempe) & & $3,0 \times 10^{6}$ & \\
\hline $\begin{array}{l}\text { C (70\% Tapioka : } 15 \% \text { KPJ : } \\
15 \% \text { T.Tempe) }\end{array}$ & $\mathrm{c}$ & & \\
\hline $\mathrm{KK}=7,48 \%$ & & & \\
\hline
\end{tabular}

Perbedaan angka lempeng total pada mi kering tapioka diduga karena karena mikroba memanfaatkan nutrisi yang berbeda pada setiap perlakuan, sehingga angka lempeng total yang terhitung berbeda-beda. Menurut Kusnandar (2010), air merupakan salah satu komponen penting yang diperlukan untuk pertumbuhan mikroba, disamping komponen nutrisi, suhu, dan $\mathrm{pH}$. Untuk dapat tumbuh mikroba memerlukan air bebas karena mikroba tidak dapat menggunakan air yang terikat kuat dalam matriks pangan. Mikroba dapat tumbuh lebih mudah dalam pangan yang mengandung kadar air, tetapi akan sulit tumbuh pada pangan dengan kadar air rendah. Kebutuhan setiap mikroba akan air untuk pertumbuhannya berbeda-beda.

Menurut SNI 01-2974-1992 tentang syarat mutu mi kering, bahwa angka lempeng total untuk mi kering maksimal 1 x $10^{6}$ koloni/gram. Angka lempeng total yang didapat pada perlakuan yaitu sebesar $6,0 \times 10^{4}-3,0 \times 10^{6} \mathrm{koloni} / \mathrm{gram}$. Angka lempeng total yang diperoleh pada sampel masih memenuhi syarat SNI mi kering untuk perlakuan A, B, D, dan E. Untuk perlakuan C tidak memenuhi syarat SNI karena angka lempeng total melebehi dari syarat mutu yang ditetapkan. 


\section{Asam Amino}

Berdasarkan uji organoleptik terbaik diperoleh produk terbaik mi tapioka dengan campuran konsentrat protei jagung dan tepung tempe adalah perlakuan $\mathrm{E}$ (Triandita, 2017). Adapun hasil uji asam amino produk terbaik terdapat pada tabel 2.

Tabel 2. Hasil Analisis Asam Amino Mi Kering Tapioka Perlakuan E (70\% Tapioka : 25\% Konsentrat Protein Jagung : 5\% Tepung Tempe Kedelai) Dibandingkan Dengan Referensi

\begin{tabular}{|c|c|c|c|c|}
\hline \multirow{2}{*}{ Asam Amino } & Jagung * & Kedelai** & FAO (1973) & Perlakuan $\mathbf{E}^{* * * *}$ \\
\hline & \multicolumn{4}{|c|}{ mg/g protein } \\
\hline L-asam aspartate & - & - & - & 570 \\
\hline L-serin & - & - & - & 230 \\
\hline L-Asam glutamat & - & - & - & 1610 \\
\hline Glisin & - & - & - & 300 \\
\hline L-Histidin & - & - & - & 260 \\
\hline L-Arginin & - & - & - & 230 \\
\hline L-Threonin & 44 & 41 & 40 & 250 \\
\hline L-Alanin & - & - & - & 860 \\
\hline L-Prolin & - & - & - & 950 \\
\hline L-Sistein & 31 & 20 & 35 & 130 \\
\hline L-Tyrosin & 57 & 82 & 30 & 860 \\
\hline L-Valin & 45 & 48 & 50 & 530 \\
\hline L-Methionin & 31 & 20 & 35 & 140 \\
\hline L-LysinHCl & 26 & 57 & 55 & 310 \\
\hline L-Isoleusin & 32 & 47 & 40 & 430 \\
\hline L-Leusin & 106 & 77 & 70 & 1300 \\
\hline L-Phenilalanin & 57 & 82 & 30 & 580 \\
\hline Keterangan : $(*)$ & & chtadi (199) & & \\
\hline$(* *)$ & & chtadi (199? & & \\
\hline$(* * *)$ & $=$ & il penelitiar & kering tapi & serlakuan E \\
\hline
\end{tabular}

Asam amino adalah senyawa organik penyusun protein yang memiliki dua buah gugus fungsional primer, yaitu gugus amin $\left(-\mathrm{NH}_{2}\right)$ dan gugus karboksil ($\mathrm{COOH}$ ). Asam amino esensial terdiri dari isoleusin, leusin, metionin, fenilalanin, treonin, valin, lisin, histidin, dan arginin (Kusnandar, 2010). Asam amino pembatas pada konsentrat protein jagung adalah lisin, pada konsentrat ini rendah akan lisin. Lisin merupakan asam amino esensial yang banyak terkandung pada daging, susu, telur, dan kacang. Adanya dua gugus amin menyebabkan lisin lebih mudah terlibat dalam reaksi kecoklatan non-enzimatis (reaksi Mailard).

Pada tepung tempe kedelai asam amino pembatasnya yaitu metionin, rendahnya metionin diharapakan dapat terkomplementasi oleh kelebihan metionin 
pada konsentrat protein jagung. Metionin merupakan asam amino esensial yang terdapat pada protein hewani 2-4\% dan protein nabati 1-2\% (Kusnandar,2010).

Berdasarkan Tabel 22, diperoleh asam amino lisin sebesar $310 \mathrm{mg} / \mathrm{g}$ pada mi kering tapioka. Rendahnya kandungan asam amino lisin pada jagung dapat dikomplementasikan dengan kandungan asam amino lisin pada tepung tempe kedelai yang tinggi sehingga asam amino lisin meningkat dari $26 \mathrm{mg} / \mathrm{g}$ menjadi $310 \mathrm{mg} / \mathrm{g}$ pada produk.

Asam amino metionin yang diperoleh pada perlakuan E yaitu sebesar 140 $\mathrm{mg} / \mathrm{g}$. Menurut Kusnandar (2010) bahwa metionin jumlahnya 1-2\% dari protein nabati. Rendahnya asam amino metionin pada kedelai dapat tertutupi oleh asam metionin pada jagung, sehingga efek pencampuran pada produk mi diperoleh sebesar $140 \mathrm{mg} / \mathrm{g}$.

\section{KESIMPULAN}

Berdasarkan hasil penelitian yang telah dilakukan mi tapioka dengan penambahan konsentrat protein jagung dan tepung tempe berpengaruh sangat nyata terhadap angka lempeng total dan perlakuan terbaik berdasarkan organoleptik adalah perlakuan E (70\% Tapioka : 25\% Konsentrat Protein Jagung : $5 \%$ Tepung Tempe) dan angka lempeng total $2,7 \times 10^{5}$ (koloni/gram) sesuai dengan syarat mutu SNI mi kering .

\section{SARAN}

Disarankan untuk peneliti selanjutnya melakukan penelitian terhadap mi tapioka dengan penambahan campuran konsentrat protein jagung dan tepung tempe. Menguji senyawa anti gizi yang terdapat pada konsentrat protein jagung dan tepung tempe sebelum digunakan dalam pencampuran bahan. Melakukan pegujian daya cerna dan umur simpan produk

\section{DAFTAR PUSTAKA}

Azima, F. (1993). Sifat Kimia dan Fungsional Konsentrat Protein Jagung. Jurnal Penelitian Andalas. 13:11-22.

Azima, F. dan Zuminiati. (1994). Pengaruh Komposisi Tepung Campuran Terhadap Karakteristik Biskuit Yang Dihasilkan. Jurnal Penelitian Andalas. 16:15-26.

Dewan Standarisasi Nasional. (1992). SNI 01-2974-1992: Mi Kering. Dewan Standarisasi Nasional. Jakarta. 
Fardiaz, S. 1993. Analisis Mikrobiologi Pangan. PT. Raja Grafindo Persada. Jakarta.

Kusnandar, F. (2010). Kimia Pangan Komponen Makro. Jakarta : PT. Dian Rakyat.

Tabel Komposisi Pangan Indonesia. (2009). Persatuan Ahli Gizi Indonesia. Jakarta: PT.Elex Media Komputindo.

Triandita, N. (2017). Potensi Konsetrat Protein Jagung sebagai Bahan Suplementasi Protein Pada Produk Pangan. Prosiding Seminar Nasional Hasil Penelitian Pertanian VII- Fakultas Pertanian UGM. ISSN: 2442-7314. 